\title{
Study on Course Teaching of Finance Based on Case Teaching Method
}

\author{
Ping Zhang \\ Economics School, Tianjin University of Finance Economics, Tianjin, 300222, China
}

\author{
Keywords: Case teaching method, Finance, Course teaching, Study
}

\begin{abstract}
To cultivate more financial talents for the society, colleges and universities have enhanced teaching and adopted innovative teaching method to help students absorb financial knowledge. Currently, case teaching method can concretize abstract knowledge. Moreover, teachers fully introduce cases in the process of classroom teaching so as to make students attracted by knowledge and improve the efficiency of classroom teaching by training their exploration capability. Therefore, this paper studies course teaching of Finance based on case teaching method so as to provide reference for the improvement of classroom teaching quality of Finance.
\end{abstract}

\section{Introduction}

Finance is a main subject in economics. As practical economics, it plays an important role in the connection of subject system. Finance is the medium of specialized courses of finance and economic theory course and manifests financial domination phenomenon regularly through fiscal phenomenon. Therefore, finance is the foundation of students' learning of specialized knowledge of economics. Currently, to improve teaching quality of finance, colleges and universities adopt innovative teaching method to arouse the interest of students in learning finance and then cultivate talents majoring in finance with comprehensive abilities for the society. As a brand new teaching method, case teaching method can help teachers implement teaching with case teaching method, combine theoretical knowledge of finance and the reality and play a vital role in the improvement of course teaching effect of Finance.

\section{Introduction to case teaching method}

Case teaching method first originated in Roman and Ancient Greek Times. It was first applied in practice in USA at the beginning of the $20^{\text {th }}$ century. Then, case teaching has developed influentially, improved increasingly in each field and produced profound influence on the world. The main purpose of case teaching method is to improve students' abilities of thinking, expansion and debate, expand their cognition of the society and strengthen their ability of solving problems. Case teaching method pays attention to rigid theoretical knowledge and more importantly combines theory and practice and abandons duck-stuffing teaching means.

In class, teachers highlight event characteristics and effects according to the manifestation of specific contents of different real events such as occurrence, process and ending and conduct discussion and analysis with students so as to allow students to master course contents better and improve their abilities of analyzing and solving problems. Finance is a course with both theory and application which plays a vital linking role in subject system. However, traditional teaching procedures pay more attention to qualitative analysis and neglect empirical analysis, thus making finance top-heavy objectively. Therefore, it is necessary to introduce case teaching method into finance so as to achieve educational objectives more effectively, which can help students integrate internal and external knowledge and understand teaching thoughts and connotations more deeply and improve students' abilities of comprehensive thinking and connection with real life and their comprehensive quality. 


\section{Course features of finance}

\section{Financial knowledge is boring.}

Finance is a subject studying all economic activities and behaviors of the government. It mainly studies basic knowledge, theory, policies and skills of finance, including state budget, budget system and management of state-owned property etc. Different from other disciplines, finance is strongly theoretical and abstract. Therefore, it makes students feel bored while listening to the lesson. They often have a smattering of knowledge of some theoretical knowledge, fail to understand and use it actually and recite contents learnt before in a hurry before test. In this way, they cannot get a good result or apply the knowledge. To avoid such teaching defects, case teaching method should be used to arouse students' interest in learning finance. Abstract concepts can be revealed vividly through the analysis and understanding of specific cases, which can help students understand theoretical knowledge. Moreover, most case materials occur in real life. Therefore, teachers can guide students to find and solve problems more smoothly and urge each student to participate positively.

\section{Finance lays particular stress on practicalness.}

Moreover, finance lays particular stress on practicalness. Finance generally involves management and practical application. Therefore, it has rich practical value. While mastering basic knowledge and theory, students should have a profound awareness of the significance of finance in economic development so as to handle financial management work in the real life correctly. However, some students cannot combine theory with practice very well. Therefore, case teaching should be introduced to solve this problem. Case teaching method can allow teachers and students to participate in teaching from the perspective of students, arouse students' learning interest and encourage them to think independently, analyze cases with existing knowledge, find problems in time and solve problems through consideration. Meanwhile, students can air their own views in the communication process, participate positively and learn to communicate and cooperate with others and use others' thoughts for reference so as to enhance advantages and avoid disadvantages. In short, case teaching method can improve students' abilities of expression, communication and problem solving and their comprehensive quality and allow them to learn under a relaxed and joyful environment.

\section{Functions of introduction of case teaching into course teaching of Finance}

The introduction of case teaching into course teaching of Finance can improve students' abilities of analyzing and solving problems. Case teaching method regards cases as the foundation of teaching and allows students to discuss and communicate mutually, analyze finance cases with the theoretical knowledge of finance learnt and think independently by improving their dominant role. For example, while teaching corporate income tax, teachers can make students distinguish Chinese and foreign corporate income taxes and analyze deficiencies of Chinese corporate income tax with case teaching method. Then, students can put forward personal ideas, combine theory and reality and analyze and solve problems effectively. Students' learning interest can be improved. Finance course is strongly theoretical. With case teaching method, students participate in practical activities by analyzing typical cases. This method can help them concretize abstract theoretical knowledge and have profound understandings of teaching contents. Meanwhile, cases selected are connected with the real life closely and can arouse students' learning interest and improve the teaching quality of finance course. Therefore, case teaching method plays a vital role in course teaching of finance.

\section{Application of case teaching method in course teaching of Finance}

\section{Improve each link of teaching.}

In the teaching process of finance, schools should make full use of case teaching method for teaching and combine theoretical knowledge and practice by improving each link of teaching so as to help students' learning of finance course and achieve teaching objectives. For example, teachers can first conduct case design and select typical cases in life in the teaching process of financial functions. Such cases must include theoretical knowledge such as state-owned property management system 
and profit distribution system of state-owned enterprises and tax revenue. Then, teachers should organize and summarize contents in cases and specify teaching purpose. Meanwhile, teachers can set questions for students about the composition, form and scale of fiscal revenue and government loan under the action of typical cases.

Second, teacher can distribute some data to students before the teaching of theoretical knowledge of finance and introduce relevant contents of cases to students with modern multimedia technology. Finally, case discussion can be conducted. For example, teachers can introduce the flood disaster suffered by Sanmenxia in 2003 which caused direct local economic losses of over 2 billion Yuan. Some financial funds would be spent in the process of reconstruction. Therefore, relevant personnel discussed the necessity of abandoning Sanmenxia. For this case, students can discuss what decisions should be made in the construction process of infrastructure and how to allocate financial funds reasonably. Therefore, students can learn financial knowledge better through the improvement of each link of teaching with case teaching method ${ }^{[2]}$.

\section{Combine theoretical knowledge and case teaching.}

Attention should be paid to the abstractness and boring feature of financial knowledge in the teaching process. Therefore, it is required to guarantee the combination of theoretical knowledge and case teaching of finance and the completion of teaching objectives so as to promote students' full absorption of financial knowledge. First, teachers must adjust teaching time based on contents in each class of finance, arrange teaching links rationally, get rid of traditional teaching mode by improving students' dominant position and plan teaching time scientifically in the process of classroom teaching so as to improve the efficiency of classroom teaching of finance. First, the best teaching method should be adopted. As there are finance majors and non-finance majors, different majors have different teaching objectives. In the teaching of finance majors, students must have solid basic knowledge of finance, especially comprehensive mastery of the classification of fiscal expenditure, principle, benefit analysis, specific expenditures, financial investment management system, social security system and fiscal subsidy system. Then teachers should reduce the teaching time of theoretical knowledge, allow students to learn more extracurricular knowledge and study by themselves through the teaching method of "writing, discussion and evaluation" and improve their interest in learning finance. In the teaching of non-finance majors, theoretical teaching should be enhanced due to students' weak basic knowledge. Meanwhile, case teaching method should be adopted for both majors. Students can discuss with each other based on cases so as to combine theory and practice closely and learn the knowledge of finance course better.

\section{Establish finance case information base.}

As finance is a course with strong operation, teaching with case teaching method can allow students to combine theoretical knowledge and cases closely so as to have better understandings of financial knowledge. Therefore, schools must establish finance case information base so as to achieve better effects of finance course teaching. It is necessary to add typical cases for the teaching of important sections based on teaching contents. after explaining theoretical knowledge of finance, teachers should guide students to have practical operation and solve actual problems with theoretical knowledge of finance correctly so as to improve their ability of practical operation. Relevant resources in the case information base can provide reference for the teaching of teachers. Therefore, cases selected by teachers must be related to teaching contents ${ }^{[4]}$.Meanwhile, cases must be real and controversial events. As there is no final conclusion on such cases, they are worth discussion. Students can put forward their views and arouse their interest in learning finance. In addition, cases should be closely related to actual life. Hot financial issues can be analyzed and finance case contents should be analyzed comprehensively from the perspective of effectiveness so as to guarantee students' comprehensive understandings of finance contents. Therefore, the establishment of finance case information base can help teachers in finance course teaching with case teaching method.

\section{Enhance discussion-type teaching.}

To improve the teaching quality of finance course, schools have enhanced case teaching. However, teachers make explanations in class and students listen to the class passively in previous teaching process of finance with case teaching method. Though students can learn some theoretical 
knowledge, such teaching mode has disadvantages. Students' initiative cannot be stimulated effectively. Therefore, teachers should change their role and improve students' dominant position in the teaching process of finance with case teaching method, allow students to participate in discussions through cases related to financial knowledge and then listen to students' views positively. For example, when explaining funds movement and supply-demand relation, teachers first select a typical case, i.e. Shenyang SAIC Automotive Transmission Co., Ltd., introduce this enterprise to students so that they can have certain understandings, and then ask students to analyze funds flow and supply relation of the enterprise. As this company involves complicated transmission production and sales business and the relation between product supply and customer demand is not composed of a single network, students must discuss mutually in class so as to combine theoretical knowledge of finance and practice. Students make a statement based on the case, communicate with each other, put forward various views, verify questions raised and prepare materials in text form so as to have full understandings of financial knowledge with case teaching method ${ }^{[5]}$.Meanwhile, students' dominant position should be improved so as to cultivate their abilities of thinking and innovation in the process of classroom teaching of finance.

\section{Conclusion}

In the teaching process of finance course, it is required to enhance the application of case teaching method in finance course teaching so that students have comprehensive understandings of teaching contents and exert functions of case teaching method by selecting typical cases and improving students' dominant position. It is good for students to learn the knowledge of finance course and have comprehensive understandings of financial knowledge.

\section{Acknowledgments}

This paper is a topic of the $12^{\text {th }}$ Five-Year Plan of Education Science of Tianjin. Topic name: Study on Establishment of Practical Teaching System of Finance in Institutions of Higher Learning.

\section{References}

[1] Zheng Jie. Application and Optimization of Case Teaching Method in Teaching Process of Finance Course. Journal of Heilongjiang College of Education, 2012(9):53-55.

[2] Liu Ye. Discussions on Course Teaching Method of Finance. Journal of Fujian Technical College of Commerce, 2011(5):10-14.

[3] Hu Donglan. Strengthen Application of Case Teaching Method in Finance Teaching. Era Economy and Trade, 2010(26):228-229.

[4] Guan Hui, Li Peng. Application of Case Teaching in Finance Major. Science and Education Herald, 2011(11):106-107.

[5] Sheng Rui. Study on Case Teaching Reform of Finance. Journal of Liaoning Economic Management Cadre Institute, Liaoning Economic Vocational Technical Institute, 2010(6):86-87,94. 